\title{
Localizing Urban Design Traditions: Gated and Edge Cities in Curitiba
}

\section{CLARA IRAZABAL}

School of Policy, Planning and Development, University of Southern California, Los Angeles, CA, USA

\begin{abstract}
Gated communities and edge cities are new forms of space production and consumption that promote changes in the character of public space and citizens' participation in public life. This study unveils the phenomena of their creation as a paradoxical attempt to return to community. Curitiba's examples of gated communities and edge cities show that, despite being internationally showcased as a model of good planning and urban design, this metropolis has not been immune to the global capital pressures and urban design tendencies occurring in many urban areas throughout the world, thus signalling both the currency and trans-nationality of these issues.
\end{abstract}

\section{Introduction}

One significant means that contemporary cities use to achieve local liveability and global prominence is the construction of the built environment. This paper examines emergent types in the production of housing developments in Curitiba, Brazil, that aim to create a contemporary city image catering for both local higher-income groups and also national and international audiences. The developments studied here can be identified as types of gated communities and edge cities. While the last 15 years have seen a flurry of literature exploring these spatial settings in a variety of geographical contexts and using myriad analytical and theoretical approaches, insufficient attention has been paid to community formation practices as causes and effects of these developments. These settlements are examined through the concepts of community, anomie and alienation.

The dichotomies of community/society and alienation/progress, taken as continuous, have long been considered determinant foundations of sociological traditions. Moreover, they have been regarded as epitomes of the conflict between tradition and modernism, between the old order and the order of modernity brought about by the industrial and democratic revolutions (Nisbet, 1966). But within the new cultural orders of post-modernism and globalization, a curious return to more primitive instances of community and alienation seems to have emerged, in the form of key warps of social organization which oppose the modern ideals of society and progress. These contestations in the socio-political and cultural arenas are reflected in the spatial public realm of contemporary cities. Political and spatial practices represent the hegemonic means by which urban elites construct status and exercise economic and symbolic power over societies, and develop exclusionary ways to redefine and reconstruct their communities. The cases examined in Curitiba shed light on these processes. They also show that there are dialectical tensions between local and global architectural and urban design epistemologies in the city, expressed in the production of these specific types of architecture and urbanism, resulting in a hybrid modern/post-modern built environment where global design traditions are temporally re-/displaced and spatially 'localized', i.e. they are reassigned different, syncretistic meanings and reconstructed forms in a new time and place.

The modern, industrial city has been reiteratively condemned as a public realm that was - and continues to be-conducive to anomie and alienation. Recent analyses of more contemporary 
types of urban development, such as gated communities or edge cities, claim that even when subverting the modernist spatial order and social ideals, these developments also produce anomie and alienation by fragmenting the city into isolated enclaves, with physical and subjective barriers that reduce permeability. While recognizing the alienating impacts at the urban, metropolitan and regional scale of gated and edge cities, this study further reveals the widespread phenomena of their creation as an attempt-however paradoxical — to return to community. The paper specifically examines the cases of Ecoville and AlphaVilles in Curitiba, as examples that are similar enough to the general notions of gated communities and edge cities, respectively. The origin of Ecoville to the 'city in the park' concept is traced as an example of a 'localization' of a global modern design tradition, but with an inverted social agenda. Within Ecoville, a revolving building - Suíte Vollard—is presented as the architectural climax of social snobbism. Then, the current and potential social and urban impacts of the new AlphaVille developments in Curitiba are explored, by both analysing them and extrapolating from their well-established precedent in Sa o Paulo.

In order to provide a theoretical framework for the analysis, the paper briefly discusses the concepts of community, anomie and alienation, on the one hand, and gated and edge cities on the other.

\section{On Community, Anomie and Alienation}

The intent in introducing the concept of community is to investigate it as a nomosmaking-and alienation-preventing - social structure. Community is generally understood as a group tied by social bonds that are deep, cohesive, continuous and fulfilling. The sense of community may be derived from physical propinquity, but can also go beyond that, to encompass the somewhat spatially disentangled communities of family, work, religious or political affiliation, and culture. Opposing the idea of community, or Gemeinschaft, is the idea of society, or Gesellschaft (in To"nnies' meaning), regarding the impersonal, contractual, large-scale ties that proliferated in the modern era, often at the expense of community. If community is indeed such an entity in conflict with society, then we can inquire into the nomic and fulfilling processes that, by their absence, lead to anomic and alienating states. If there is a negative correlation between community and anomie and alienation, then one can inquire into the character of social ties as a nomosbuilding and self-fulfilling instrumentality, that is, of community as a social arrangement that creates the sort of order in which one can experience oneself and one's life as making sense. Every individual benefits from ongoing social validation of identity, place and purpose in the world. Just as an individual's deprivation of relationship with others can plunge her into anomie and alienation, so others' actions and presence have the capacity to substantially contribute to sustaining for her that nomos and positive self-esteem by which she can feel at home in the world. The plausibility and stability of a personal world is delicately intertwined with the stability of the social world in which a person is immersed, dependent upon the quality and continuity of significant relationships with others. Indeed, it has been long understood and accepted that "sociability is a crucial nomic instrumentality in our society" (Berger \& Kellner, 1964/1974, p. 160).

Alienation, for its part, is generally regarded as an individual's state of estrangement, anomie and rootlessness, caused by a detachment from the ties of community and its shared sense of morality. Alienation entails the estrangement of individuals from one another, or from specific situations or processes. The sociological discussion of the term relates to Marx's argument that estrangement is a consequence of social structures that oppress people, denying them their 
essential humanity. As such, alienation would be an objective condition inherent in the social and economic arrangements of capitalism. With the advent of modernity, alienation came to be seen as an inversion of progress. Subsequent researchers, however, have tended to neglect these structural considerations, and have instead attempted to operationalize the concept in terms of a range of specific cognitive and attitudinal characteristics. Thus, Melvin Seeman (1959) stated that the psychological state of alienation comprised "the dimensions of powerlessness, meaninglessness, isolation, normlessness, and self-estrangement” (cited in Marshall, 1994, p. 910).

It is contended that while in contemporary modernist or industrial cities depersonalized citizens, estranged from themselves and the larger collective, may go through great struggles in an attempt to overcome feelings of powerlessness, meaninglessness, isolation and normlessness, the new exclusive urban enclaves provide mechanisms for a relative overcoming of anomie and alienation by means of collective ownership and control—at least for those who can afford them. The 'community' of owners thus formed, despite the fact that it may display a sophisticated, high-tech lifestyle, may be regarded as 'primitive' in an ontological and teleological sense, signalling a return from the type of 'organic' solidarity — based on complementary differences between individuals — that held together modern societies, to a 'mechanical' solidarity — based on similarity between individuals—in Durkheim's terminology. 'Curiously, the notion of a contained community where mechanical solidarity may easily flourish is asserted in the case studies presented here by the use of the French suffix -ville, meaning village, in the names of the two types of developments-Ecoville and AlphaVilles. Moreover, the prefixes eco and alpha evoke ecological balance and returns to origins or beginnings, respectively. Alpha also connotes an idea of dominance or superiority, being at the top or at the beginning of everything.

\section{On Gated Communities and Edge Cities}

Gated communities represent a new type of urbanism that reinterprets the meaning and form of community. In many cases, particularly in the developing world, they are also a vehicle through which local elites attract global capital and global design traditions are localized. Variously recognized as walled communities, (fortified) enclaves, fortress cities, edge cities—or its Brazilian counterpart, condominios fechados (closed condominiums) - the phenomenon has been studied by many theoreticians (for example, Garreau, 1991; Davis, 1990; Abrahamson, 1996; Ellin, 1996; Caldeira, 1999; Low, 2003). The gated community phenomenon, whose global proportions are by now well established in theoretical and empirical literature, comes in different types—such as private residential communities including condominiums and homeowners' associations, retail and resort communities, and office and industrial parks, or in combinations of all of the above-and occurs primarily at the periphery of cities as part of the edge-city phenomenon. Generally, authors agree that such enclaves contain at least the following basic characteristics:

concentrations of residents who share a distinctive status that is important to their identity; specialized stores and institutions that provide local support for the residents' distinctive lifestyle; [and] a strong tie between that lifestyle and the geographic space the residents occupy. The place then becomes a calling card, symbolizing the social identities of the residents of the enclave. (Abrahamson, 1996, p. 13)

Driven by both fear and the quest for safety and status, residents of enclaves isolate themselves from the animosities and lifestyles of outsiders. In addition to actual walls and fences, many 
other design props are used to keep people-both insiders and outsiders - in their place (Ellin, 1996). The actions of local governments - through zoning ordinances, fire and safety regulations, highway construction projects, and so on-are other effective means of creating and maintaining segregation.

The fear of violence is indeed one of the main motivations and justifications for these developments. In order to create a sense of 'place' and 'community', these fortified enclaves turn their backs to the city, surrounded by walls, gates or green belts. They employ security systems and gates of various types, in a range from the fairly unobtrusive to the highly obvious.

Neighbourhood associations may decide upon a range of approaches to active security, from volunteer watches to the hiring of security guards and the enforcement of rules of inclusion and exclusion (Ellin, 1996). However, security and control do not relate exclusively to the prevention of crime and the assuring of security. Instead, the notion of security is also strongly tied to various other meanings such as 'happiness', 'harmony' and, paradoxically, 'freedom' (Caldeira, 1999). Although historically the term enclave has been mainly given to religious, racial or ethnic concentrations, or the combinations thereof, contemporary urban trends evidence that this use is too confined. Increasingly, lifestyle and wealth are also the bases of enclaves, and these traits even become predominant in the formation of closed communities in many contemporary societies. Gated communities in Brazil are such a case. They tend to be class-homogeneous communities, mostly for the middle and upper classes.

The packaging of these developments plays a definite role in the status they are assumed to confer. First World names, examples and concepts are also strategically used in the advertisement of these developments to allure potential residents. Usually, they:

present the image of islands to which one can return every day, in order to escape from the city and its deteriorated environment and to encounter an exclusive world of pleasure among peers. The image of the enclaves, therefore, is opposed to the image of the city as a deteriorated world pervaded by not only pollution and noise but, more importantly, confusion and mixture, that is, social heterogeneity. (Caldeira, 1999, p. 88)

Fortified enclaves deny many of the basic elements that previously constituted the experience of modernity in the urban realm, as analysed by, for example, Benjamin (1969), Berman (1982), Harvey (1985) and Holston (1989). Spatially, cities that become fragmented by fortified enclaves lose the principles of openness and free circulation that were significant organizing values of modern cities. Although the ideals of openness, freedom and citizenship that constituted modernity have never been completely fulfilled, they continue to have an important referential role in most societies. The current public experiences of cities fragmented by gated communities, however, are blatantly subverting those ideals. The principles of segregation and isolation that these developments enact resist the quintessential urban experience of modernity, characterized by such traits as:

primacy of streets and their openness; free circulation of crowds and vehicles; impersonal and anonymous encounters of the pedestrian; unprogrammed public enjoyment and congregation in streets and squares; and the presence of people from different social backgrounds strolling and gazing at those passing by, looking at store windows, shopping, and sitting in cafes, joining political demonstrations, or using 
spaces especially designed for the entertainment of the masses. (Caldeira, 1999, p.

93)

The spatial paradox repeats itself at many levels. Defensive design, rather than an increase in safety, may actually work in the opposite way. When some groups are denied access to certain areas, and different groups cannot interact in public space, the morphologies of fear that conform defensible architecture and urbanism may promote conflict rather than prevent it, by making clear the extension of social inequalities and the lack of commonalities between groups. Furthermore, it becomes impossible to maintain the ideals-even as fictions-of the modern public, and its democratic principles of equality and freedom. Among the conditions necessary for democracy is the acknowledgement-as co-citizens - that people from different social groups have similar rights. If this is true, it is clear that contemporary cities segregated by gated enclaves are not environments that generate conditions conducive to democracy. Rather, they foster inequality and the sense that different groups belong to separate universes and have irreconcilable claims. The architecture of the enclaves entails a certain social logic that does not strengthen citizenship. Rather, it contributes to its fragmentation into multiple levels of unequal citizenship (Blakely \& Snyder, 1997; Low, 2003; Blandy \& Lister, 2005).

Encompassing greater scale and programmatic scope than gated communities are edge cities (Garreau, 1991), also known as outer cities or satellite urban villages. These began to appear in the early 1980s in the United States (US). In addition to residences, edge cities include business centres, shopping malls, and some public spaces, amenities and cultural facilities. As such, they sometimes rival central cities' downtowns. Typically, these developments depart from modern urbanism in their effort to become more user friendly, with more attention devoted to the production of quality architecture and urban space, through the wilful use of ornament, colour, detail and narrative (Ellin, 1996). While Garreau conceives this type of development as a utopian quest to reunite home, work and recreation, others see these urbanizations as natural outcomes of the current service-and information-based economy, turning the traditional industrial metropolis inside out. Many have been critical of the exclusionary and polarizing social effects of edge cities, since they are typically located in affluent areas, whereas blue-collar workers and poor people remain segregated in central cities or older suburbs. Scholars and practitioners have warned that the exacerbated division by race, culture and income in many edge cities poses a great threat to society's well being (Byrum, 1992; Orfield, 1998). This threat can be seen in the conditions of some edge cities in their restriction of civil liberties, enforced conformity of residential communities, the racial or classist character of developments, conflicts between developers and preservationists, complications for regional planning, and other such traits. Despite these criticisms, edge cities are a growing phenomenon in the urbanization of the US and many other First as well as Third World cities. In some cases, such as AlphaVille Graciosa, gated communities evolve into a sort of hybrid, semi-gated edge city.

In some Brazilian cities - for example in Sa o Paulo after the mid 1970s — there has been resistance from excluded residents to the instillation of the new social order that gated and edge enclaves promote, and to its embedded constraints on citizenship and democracy. In Curitiba, however, the phenomenon of the creation of these types of developments might be too recentand citizens' consciousness about the developments' obstruction to the exercise of citizenship might be too low - to provide any tangible resistance in the city. Fortunately, the planning elite, through the IPPUC (Instituto de Pesquisa e Planejamento Urbano de Curitiba), is starting to acknowledge and react to the social costs of gated communities, in view of the negative effects 
that the rapid proliferation of these developments are causing on the continuity of the street network in the metropolitan area. As a start, the city has passed an ordinance that constrains the size of new gated communities. This is a positive instance of adaptation/localization of global urbanistic trends.

With the concepts of gated communities and edge cities and their respective effects in mind, let us now turn to three case studies from Curitiba: Ecoville, Suíte Vollard and AlphaVilles. Ecoville and SuÍte Vollard: Reinterpretations of Modernist Design Traditions.

As suggested above, Durkheim's mechanical solidarity within a multi-class, multi-ethnic world — such as the one we inhabit in contemporary cities — cannot be attained except through a deliberate, assertive effort to exclude 'others'. In the case of Ecoville in Curitiba, the conditions for this exclusion were sought from the beginning of the development, as evidenced by the politics of the sub-division's creation.

The 1966 Master Plan of Curitiba conceived a radial city, with the creation of five structural transportation and land-use axes that would eventually radiate from the city centre to different areas of the city. These axes were meant to guide and control growth. The fifth of these axesConectora 5-did not function as a catalyst of growth for more than two decades, however. Given this axis's proximity to the Industrial City of Curitiba, the rationale for its creation asserted that the land was going to be used for housing developments for industrial workers. In reality, however, the land along the axis was acquired by an oligopoly of developers linked to the government elite, and left undeveloped for 20 or more years, while land prices increased. Thus, until recently Conectora 5 only functioned as a mechanism to promote great land value appreciation along the axis. Recently, a unique zoning ordinance was created for the areasubsequently renamed Ecoville — and the area was opened for real-estate development. Today, Ecoville land values have some of the highest levels of appreciation in the Curitiba metro region.

The spatial mechanism that propitiates the conditions for mechanical solidarity to unravel in Ecoville is the local reinterpretation of a global modern design tradition. Despite the recent conception of this sub-division in Curitiba, the design concept of Ecoville can be traced back to the modernist 'city in the park' concept. Since the 1930s, superblock planning has become increasingly allied with theories emanating from the Congre`s internationale d'Architecture Moderne (International Congress of Modern Architecture, or CIAM). According to modernist ideas set down in CIAM's 1933 Athens Charter, the modern city was meant to be "a composition of freestanding buildings, set in a diffuse landscape of foliage and organized by a loose grid of high-speed arteries" (Le Corbusier, 1973). The urban renewal policies of the 1950s and 1960s in the US, and several urban projects elsewhere in the world, made room for these types of urban spatial schemes. Old city quarters were torn down to build new, impoverished celebrations of the modern "'city in the park' - without the park" (Kostof, 1991, pp. 154, 331). The modernist urbanism had an important socio-political agenda, though, despite how utopian it has proven to be: "the erasure of social difference and creation of equality in the rational city of the future mastered by the avantgarde architect” (Caldeira, 1999, p. 95). By subverting the traditional figure- ground code of urban order, modernist city streets "appear as continuous voids and buildings as sculptural figures" (Holston, 1989, p. 125), erasing the representational distinction between public and private. The Corbusian design vision is so explicitly referenced in Ecoville that the real-estate company Plaenge is currently constructing a building there called 'Le Corbusier' (Figure 1). 
In contrast with its original social agenda, in many instances the instrumentation of modernist planning paradoxically produced inequality, highlighting rather than erasing differences. In both Ecoville and AlphaVilles in Curitiba, modernist design principles are used to intentionally minimize public spaces rather than to erase private spaces and produce a totally unified public. Caldeira, who has compared privatized enclaves in Sa o Paulo and Los Angeles, asserts that the aim of such communities is "to enlarge specific private domains so that they will fulfill public functions, but in a segregated way” (1999, p. 96).

The modernist urban concept of the 'city in the park', long abandoned by architects and planners in First World countries and heavily criticized for its negative consequences to urban integration and a social sense of belonging, has been redefined in Curitiba to make it appealing to the higherincome social class. Even with a different, more avant-garde name in consonance with the global discourses of the time, Curitiba's Ecoville presents the same type of high-rise, isolated residential towers as contained in modern visions of cities. Lacking the 'universal space' promoted by those cities-in-the-park as their public realm, however, the spaces in between the residential buildings in Ecoville are disconnected and fenced off. Moreover, the spatial amenities within each condominium are privatized, exacerbating the large-scale results of the social and urban alienation caused by this type of development, while at the same time granting the residents an alternative, controlled and exclusionist sense of community.

In Ecoville, modern design principles subvert modern social ideals. On the one hand, the design devices of modernism are selectively re-appropriated and edited to destroy modern public space and life-through the destruction of both street space and experience through the creation of highways and isolated buildings. On the other hand, the way these design strategies are used erases any possibility of the realization of modern fictions such as equality, transparency and a more democratic public sphere-sought in the modernist city through the use of glass fac,ades, design uniformity and universal public space. Instead of creating an urban space in which the distinctions between public and private disappear - making all space public as the modernists intended-the proposal in Ecoville was for a series of high-rise buildings in private parks, without a collective urban principle to aggregate them. As such, Ecoville is a 'localization' of a global modern design tradition devoid of the original modern social agenda; or worse still, with an 'inverted' social agenda.

The inverted social agenda favours the opposite of modernist ideals of equality, transparency and democracy. This appears in a growing trend towards the institutionalization and standardization of 'crime prevention through environmental design' — in which largely inoffensive design guidelines a` la Oscar Newman’s Defensible Space (Newman, 1972) have escalated to the closures of streets, gating of neighbourhoods and the design of 'defensive architecture' (Ellin, 1996, p. 72). The results of the latter are fortress-like buildings that retreat from their surrounding urban contexts, with patrolled gates and an inward focus upon semi-private spaces which may include amenities such as lavish gardens, pools, gymnasiums, multi-purpose rooms, etc. Physical distinctiveness is provided by some architectural details-e.g. shape, materials and colour of buildings - and an emphasis on landscaping with the provision of focal points such as fountains or sculptures, small plazas, gazebos and the like, within an aesthetic of security (Figure 2).

One particular building in Ecoville deserves special analysis: Suı́te Vollard, a rotating apartment building. Sur te Vollard was built by Moro, one of the most prominent real-estate companies in 
Brazil. The company claims to be radically avant-garde, trying to create-through its rhetoric, but not necessarily its designs - a competitive advantage for capturing the imagination of potential clients. The names of Moro’s buildings, many of them in foreign languages-e.g. Cote D’Azur, Crystal Palace, Golden Palace, etc.-are meant to elicit status derived from evocations of far-away, First World places from North America or Europe. Significantly enough, Moro is one of the few real-estate companies that benefited from the creation of Conectora 5. It owns important lots of land along this corridor in Ecoville. Moro advertises the fact that its buildings in Ecoville, including Suı́te Vollard, are in close proximity to a sizable park-Barigu" i—and to a big-box hypermarket-Carrefour Campagnat-while at the same time conveniently located at the outskirts of the city of Curitiba. In other words, the city is accessible, yet the residents of Ecoville do not have to suffer its urban conditions-perceived as negative-within their suburban haven. Conveniently enough, the panoramic vistas of Curitiba offered by these buildings are advertised as some of their most desirable traits (Figure 3). Ironically, the Conectora 5 "was not put to use ...until there was enough purchasing power in Curitiba to afford an apartment in a rotating building” (Urban, 1998, p. 2).

Even though Moro's buildings are usually of a rather conventional architecture, for the design of Sur te Vollard the company created something unheard of (Figure 4). According to Moro, Sur'te Vollard is the proper product for a new millennium: "At the threshold of the Third Millennium, Moro is preparing itself to grant the future to Curitibanos: Suí te Vollard is the first rotating [multifamily, residential] building in the world” (Moro S/A Construc, o es Civis, 2000b). It turns out that Moro may have gone too far with this ambitious project, however. While the building was initially expected to be completed by December 1996 (Moro S/A Construc,o oes Civis, 1994), it remained unfinished and uninhabited in mid 2004. In 1998, the price of an apartment in Sur'te Vollard was about R\$ 336 000, which is higher than the average home price in Curitiba, where 'fixed-in-place' apartments in the same area were worth approximately half that amount (Epoca, 1998). After postponing the opening several times, Sur'te Vollard had still not been inaugurated, and only five of the 11 apartments had been sold as of May 2000, at R\$ 400000 (Moro S/A Construc, o es Civis, 2003).

Sur'te Vollard was designed by architect Bruno de Franco, one of the owners of Moro. The building has eleven 268-square-metre apartments, one per floor. On top of the concrete floor of each apartment there is a gyrating steel ring that constitutes the platform upon which is located the large, round living room. This platform is designed to offer both high load resistance and smooth movement, with no deformations, vibrations or noise. The residents of each apartment can operate the rotation of this ring by remote control or by fixed, programmable timers that allow the user to schedule the start and end of a movement. A complete rotation takes 30 minutes. A fixed balcony is located along the perimeter of this rotating ring (Figure 5). Inspired by revolving restaurants and vista terraces on top of commercial buildings, which attract tourists in many cities around the world, and by the more limited examples of individual houses that revolve to seek optimal climatic conditions and energy consumption in harsh climates-e.g. in northern Europe - these precedents became deliriously stretched into an extravagant building where the purpose of the rotation of the apartments is merely hedonistic. In Sur te Vollard, emphasis on technological inventiveness - another modernist characteristic - is displayed, but not as an instrument of social progress, such as would be the case with the mass production of housing at the peak of the modern movement in the early and middle decades of the 20th century, for instance. 
Curiously, although Suíte Vollard embraces the glass fac, ades and transparency of modernism and its disclosure of private life, the intent is not to manifest social equality, but rather to display social difference. Targeted to young, successful professionals, the conception of the studio loft is exhibitionist here, 'to see and to be seen'. In the artistic rendering of Figure 6, a slim, half-naked young woman is depicted walking carefree about the transparent apartment (Figure 6).

According to Moro's promise, "this loft studio ... is going to grant its resident status and sophistication” (Moro S/A Construc, o es Civis, 2000b).

Significantly enough, Moro appropriated the name, symbolic power, boldness and eroticism of a collection of significant works by the late Spanish/French painter Pablo Picasso (1881-1973) to distinctly identify each apartment in Suí te Vollard. Thus, the surface of the entrance door of each apartment depicts a reproduction of an assigned 'Picasso'-e.g. Bullfighter Woman, Minotaur, Drunk and Women, Three Naked Women by a Window, or Man Undressing a Woman, to name but a few. Residents of these apartments may then daydream that they are enacting their personal 'Picasso' fantasy as they enter through the paintings/doors into the private realm of their homes. The painted doors also offer rich potential as 'self-presentation cards' to visitors.

Several other companies share in the oligopoly of construction in Ecoville, such as Tha'. Among many other developments, Tha' recently launched the building Rio da Prata, with only one 630square-metre apartment per floor. Impressive in size alone, these apartments seem shockingly lavish when compared to the need for affordable housing in Curitiba and, even more specifically, when compared to the meagre number of public housing units built each year there and the thousands of Curitibanos currently on waiting lists for them at the Cohab Curitiba (the municipal housing agency of Curitiba, Companhia de Habitac,a a o Popular de Curitiba). In 2002 there were 2806 affordable housing units produced, and 62712 households on the waiting list. 5 In other words, these developments occur in the widening gap between the haves and have-nots in Curitiba — as they do in most contemporary cities — a trend widely attributed to unchecked capitalist globalization.

In anticipation of the potential limitation that an exclusively residential suburb might generate for these companies' profits—and hence initiating the conditions of an edge city-Moro has recently launched a commercial complex within Ecoville. Like Ecoville, EcoBusiness, as it is called, employs the same prefix 'eco' without any real referent to either ecological design or function. While a number of eco-industrial and eco-business parks are being created in many cities around the world —including a proposal for one in Porto Alegre, Brazil—Moro's EcoBusiness merely refers to four identical, seven-storied, conventional office buildings. With no sense of urban design articulation to animate the bulky buildings or to give a sense of unity to the complex, or even to create an elaborated relation between the design and the public realm of the street, EcoBusiness is merely a profit-driven, form-follows-function modernist design, despite the environmentalist reference.

Even though the design of buildings in Ecoville is aimed at offering extra comfort and services to residents, the limited lot sizes do not allow for the developments to be stretched to the production of a virtually self-sufficient community, a self-contained edge city of sorts. In addition, contained in their lots, the buildings are directed inward and do not interfere with the street network, which remains potentially accessible to all. However, further increasing urban segregation-by-selfsufficiency, some of Curitiba's developers have engaged in the creation of even larger gated 
communities of master-planned sub-divisions. This is the newer trend in residential architecture in Curitiba, and many communities of this sort have been sprouting in the metropolitan area over the last decade.

\section{AlphaVilles: Reinterpretations of a Post-modern Design Tradition}

While gated communities are being developed in many other cities around the developing world besides Curitiba, a less common phenomenon in those cities is the creation of semi-gated edge cities - semi-fortified, self-sufficient sub-divisions that include many urban services. When communities become too large to be contained as isolated islands within walls or fences, and their service and commercial offerings require a larger pool of clients and workers than the one residents can provide to become functional and profitable, fortified enclaves may turn into semigated edge cities, becoming hybrid developments with closed, private residential enclaves and open, public commercial and service areas. Curitiba is one of several cities in Brazil where the big corporation AlphaVille Urbanismo is creating such semi-gated edge cities, as analysed here, after describing their genealogy.

In 1974, the development firm Construtora Albuquerque, Takaoka S.A., launched the first AlphaVille sub-division in the metropolitan region of Sa o Paulo. Over the years, this development proved to be profitable and attractive, and the residential demands of the Brazilian and world capitalist elite had evolved in such a manner that the firm AlphaVille Urbanismo S.A. was founded in 1995 to focus exclusively on the design, construction and marketing of this model of urbanization. The company claimed that it was reinvigorating itself with new criteria for urban organization, responding to new housing requirements "according to globalized expectations, especially in regards to the protection of and respect for the environment, recreation, education, and the satisfaction of the commercial and service needs of the residents" (AlphaVille, 1999). After several successful developments in Sa o Paulo, the AlphaVille concept was ready to be launched in other cities and states of Brazil. Currently, AlphaVille Urbanismo has built seven developments, has 15 new developments in the making, and is marketing four others, including two new ones in Curitiba (AlphaVille, 2004). Most developments are virtually self-sufficient with regard to retail and services, with over 1500 establishments (schools, restaurants, health services, offices, banks, stores, etc.). Only in the state of Parana' are there four such complexes in the cities of Londrina, Maringa' and Curitiba.

In the metropolitan area of Curitiba, the company introduced to the market AlphaVille Graciosa in 2002 and AlphaVille Pinheiros in 2003. Alphaville Graciosa is an example of a Brazilian gated or semi-gated edge city, larger than the usual residential condominios fechados and containing commercial and office complexes, a semblance of public space, and fanciful architecture that caters to the status-seeking attitudes of wealthier Curitibanos. AlphaVille Graciosa is located in the municipality of Pinhais, in the north-eastern metropolitan region of Curitiba, in 2479808.4 square metres of rural land. The design is by the local architectural and urban design firm of Alfred Willer Arquitetura e Planejamento in Curitiba, under the close supervision of AlphaVille Urbanismo of São Paulo.

The firms won several AsBEA (Brazilian Association of Architectural Firms) awards in 2002 for their co-ordination of the environmental study, the Master Plan, and the architectural projects of such community buildings as: the shopping centre AlphaMall, which received an honorary mention in the category of commercial buildings; the ClubHouse; and the chapel Capela de AlphaVille Graciosa. That same year, AlphaVille Graciosa also won the Master Imobilia'rio 
2002, a prestigious real-estate award that granted national recognition to the master-planned subdivision. In addition, AlphaVille Graciosa won two awards in 2003 granted by the Association of Sales and Marketing Leaders in Brazil (Associac,a o dos Dirigentes de Vendas e Marketing do Brasil, ADVB): the Top Social given to its Community Centre Centro de Convivência e Aprendizado da Graciosa, in Colombo, Curitiba; and the Top Ecologia, due to its "pioneering development in an ecological paradise” (ADVB, 2003) (Figure 7).

For the superintendent of AlphaVille, Nuno Lopes Alves, "the award[s] shed light on programs that demonstrate that the coexistence of a profitable development and full respect to nature is possible, in addition to offering incisive responses to social problems” (Recicla'veis, 2004). For a few geographers and environmentalists interviewed in Curitiba, however, the so-called ecological approach to development has been mainly an instrument of promoting a politically correct image that has resulted in an extremely profitable marketing approach for the company (Sa'́nchez, 2003; Moura, pers. comm., 2004; Urban, pers. comm., May-September 2004). In fact, AlphaVilles Graciosa and Pinheiros have been extremely successful as real-estate ventures. Rather than following the initial plan of having three sale phases, one every two years, the surprising demand caused all the lots to be offered at once in both developments.

AlphaVille Graciosa is located in an area of environmental fragility that includes river basin and forest preservation areas. These areas, together with the golf course, supposedly determined the design of the lots. The complex is conveniently accessed from Curitiba by a freeway (Estrada da Graciosa) that connects the city to a coastal mountain range (Serra do Mar). This development has required some $\mathrm{R} \$ 60$ million in investment. The development has one commercial and four residential clusters with a total of 1218 lots - 1113 lots for single-family residences (of 7007800 square metres each), 20 multi-family lots (for buildings up to five stories high) and 85 lots for commerce and services. It also has 436687.44 square metres for institutional uses and 648 717.89 square metres for recreational areas. In addition to an 18-hole golf course, forest and green areas, Graciosa will have a large social and sport complex, AlphaVille Graciosa Clube-a 2500-square-metre facility with pools, tennis, volleyball and soccer fields, a bar, a restaurant, stores, and other sports and social amenities (Figure 8).

Some environmental restrictions had to be taken into account in the design of the complex, according to the new law for the protection of river basins enacted by the legislative assembly of the Parana' State in 1998. These include the preservation of two areas of native pine trees (the Araucaria). According to AlphaVille Urbanismo, the native forests-306 600 square metres of the largest urban reserve of Araucaria in Brazil-would have disappeared if the company had not intervened with substantial measures, such as creating green belts around the forests that protected them from winds and infesting species, and fencing off some recovery areas. Existing trails were recuperated and reconditioned for use in guided environmental education tours. According to the tour company, the prohibition of development in the river basins led to the abandonment and deterioration of natural environments around Curitiba. By allowing the occupation of these areas under the criteria of the new law, the company claims, the state government effectively conciliated land use and environmental preservation. This is only a partial truth, however.

It may be that some preservation is accomplished inside the gated communities where the private company is actively controlling the dual processes of land use and environmental preservation, but this does not consider the damaging externalities happening outside the developments' 
boundaries. The fact is that these new edge cities and a few new industrial districts created in their surroundings are transforming the local character, rapidly and haphazardly attracting new uses and squatter development to the area. Without effective public control and private collaboration, preservation is at best a piecemeal approach that compromises the lasting and comprehensive sustainability of the region.

According to Teresa Urban (pers. comm., May-September 2004), the law was speedily approved by the metropolitan planning agency Comec (Coordinac,ão Metropolitana de Curitiba) without following proper democratic protocols, with the objective of freeing water basin land for subdivisions targeted at upper classes. To this end, Comec has even proposed to deactivate the reservoirs in the area. This approach destroyed the indispensable unity of the basin, creating 'free zones' that were not subjected to comprehensive basin planning. In addition, the law developed independently of the process for the definition of the State Law of Water Resources, which aimed to coherently establish the planning and management of each water basin in the state. Urban further claims that it was not the prohibition of development in river basins that led to the abandonment and deterioration of such environments. Rather, it was disrespect for the established preservation policies that caused such disrepair. Moreover, the 'preserved landscapes’ within AlphaVilles are truly constructed ones and not the originals (Figure 9).

Since neither AlphaVille Graciosa nor Pinheiros has been completely inhabited yet, no postoccupancy evaluation can be conducted on them. Therefore reference is made to their predecessor AlphaVille Sa o Paulo (SP), which acts as a harbinger of some factors that may become characteristic of homologous developments in Curitiba; among them, the socioeconomic status of its residents, their not-in-my-back-yard (NIMBY) attitudes and type of (mechanical) solidarity, and issues of traffic congestion, control and security.

Considered the precursor of edge cities in Brazil, the AlphaVille SP has a fixed population of approximately 32 000-34 000 people and a floating population of some 120000 people per day in AlphaVille Empresarial, its commercial area.

Residents of AlphaVille SP are from the upper-middle or high-income classes. In 1997, research by DataFolha revealed that $46 \%$ of monthly family incomes in AlphaVille SP were between 20 and 80 times the minimum salary of R\$2721, and 36\% had an income higher than 80 times the minimum salary. Educational levels and access to information and information technology are also very high in this development, particularly as compared to the surrounding area.

From 1998 to 2003, AlphaVille SP had its own newspaper and Intranet - CityAlpha. Through the e-mail discussion group at this web site, residents could denounce and complain about regulations that were not followed by other residents or that were non-enforced by the security and management team of AlphaVille. From loitering to pet policies, residents made use of sophisticated media and computer technology to reinforce policing. There was also a studio for TV AlphaVille. Sometimes these open channels for communication were paradoxically used against the actions of the company AlphaVille, as was the case with some resistance expressed by residents to the creation of Objetivo College, for which 60 Araucaria pines were cut in a protected area of a river basin (CityAlpha, 1999b). Residents also defied AlphaVille regarding the construction of a shopping centre, and certain other buildings within the development. Thus, CityAlpha contributed to the development of NIMBY attitudes and political activism among many AlphaVille residents, whose behaviour tended to change from generalized civic apathy to a 
growing concern for and action against menaces to their status and the real-estate values of their properties.

On a cautionary note, however, the haven suggested by the advertisement of the development has been threatened by growing insecurity within its walls. For instance, Alvaro Garcia, a 15-year resident of AlphaVille SP, claimed that he and his wife were victims of robbery twice in 18 months (in July 1998 and on 24 December 1999). In both robberies, thieves collected from the Garcias money, watches, cellular phones and cars, including a BMW 540i. Mr. Garcia complained:

Theoretically, we moved to AlphaVille [SP] seeking not only comfort, but mainly the apparently reinforced Security [sic]. I would appreciate it if actions were taken to prevent such crimes, ever more common in great metropolises, and which sadly arrived to our neighborhood without any ceremony. (CitiAlpha, 1999b)

Control is not only deployed to growth, access and security in AlphaVille SP. Way of life and appearance are also highly supervised in these types of developments. At times, this surveillance can become quite oppressive. For instance, in an interview in a popular magazine in November 1999, the Brazilian actor and singer Maurí cio Mattar complained about neighbour surveillance in AlphaVille SP: "If I go without shoes to the entrance of my house, people accuse me of being crazy". He claimed that there were too many nouveau riche living in AlphaVille SP, and therefore there was "no freedom to go out to the streets if your shoes do not properly match your outfit, because neighbors would notice". Feeling oppressed, Mattar announced that he had decided to move to Rio de Janeiro, where he "can wear a swimming suit till 8 p.m. in the street" (Veja, 1999).

Given AlphaVille SP's large population of residents, floating workers and visitors, another major difficulty there is heavy traffic in on the main access freeway. Congestion has become so serious that some have abandoned their plans to live in the development. In 2000, 20-30\% of the lots were unoccupied, which is a high vacancy rate for this type of development. However, two other major roads were under construction that would serve the development, and these were expected to increase the demand for lots and apartments.

Despite the aforementioned pitfalls and the disenchantment of some residents, the housing demand in gated communities in Sa o Paulo is generally larger than the supply. According to surveys by MAS in August 1999, security is the number one problem for most residents of the west area of the São Paulo metropolitan region (Folha de Sa o Paulo, 1999; CityAlpha, 2000), and this concern fosters the demand for housing in gated developments. Thus, several other fortified enclaves have since been launched in different areas of the metropolitan region.

What can we extrapolate from all of this regarding the development of AlphaVilles Graciosa and Pinheiros in Curitiba? It may be too early to tell, but based on the experience of AlphaVille SP, one would caution about the probability that AlphaVilles Graciosa and Pinheiros will cultivate the general negative effects to democracy and citizenship that have been discussed for gated and edge cities in general, which these types of exclusive developments can help to further institutionalize. In addition, just as in the case of AlphaVille SP, there may be paradoxical effects to security and transportation, elicited by the exacerbation of social and spatial inequalities in and out of the walls of the complexes, the exaltation of fear often associated with fortified 
enclaves, and the lack of prevention of the negative impacts that gated developments can cause upon the metropolitan job/housing balance, as well as upon efficiency and connectivity of the transportation system, regional tax equity, sprawling development patterns and environmental regional planning.

Alphaville Urbanismo cannot remain aloof from problems of security, transportation and the supply of blue-collar labour that could impact the real-estate success of the developments AlphaVilles Graciosa and Pinheiros. How is the company responding to some of these challenges? Alphaville Urbanismo had to take a proactive stance in order to face the challenges to the security of residents and their properties in AlphaVilles Graciosa and Pinheiros, because of the acute inequalities made apparent by the complex. To deal with social problems in the neighbouring communities of favela Vila Zumbi in the municipality of Colombo- with 12000 inhabitants, many unemployed or underemployed —and the poor community of Bonilauri, in Pinhais, AlphaVille Urbanismo created the AlphaVille Foundation for the management of projects in the areas of environmental preservation, education and training. In partnership with the municipality of Colombo, AlphaVille Foundation created in 2000 the Graciosa Community and Learning Centre (Centro de Convivência e Aprendizado da Graciosa) in the neighbouring Vila Zumbi. The centre offers the training required for the types of jobs available at AlphaVille Graciosa-i.e. in areas such as gardening, restaurant or retail assistance, sewing and craftsmanship, and other social services. There are plans to replicate this programme in other AlphaVille communities whose neighbouring barrios have high rates of poverty, crime and unemployment.

For some social observers, however, these efforts are old populist measures that are more effective as marketing strategies for the company and pacifying programmes for the targeted population, rather than as structural transformative policies (Moura, pers. comm., 2004). To be sure, it is laudable that a private company invests in social programmes, however late this seems to be starting for AlphaVille Urbanismo (after almost 10 years and more than 10 built developments). However, social indicators in Curitiba speak loudly of the need for heavy investment in affordable housing, basic infrastructure, health and living wages. The training of people to perform the underpaid jobs of the gated communities will only perpetuate existing inequalities, if the programme is performed in isolation. Ideally, private enterprise should commit more efforts and resources to promoting social equity. The municipal and state governments, for their part, should provide guidance, incentives and a legal framework in which more systemic, effective interventions of private monies and programmes and public-private partnerships can occur.

Regarding transportation, AlphaVille Urbanismo paved and extended several kilometres of the Graciosa freeway to give access to the new AlphaVille complexes. It also upgraded its infrastructure and design (trough landscaping, medians, pedestrian paths, etc.). In addition, the recent inauguration of an eastern perimeter freeway called Contorno Leste has made access to the two AlphaVille condominiums easier and faster. On the one hand, it is laudable that the company contributed to the upgrading of public infrastructure, even though this was essential to the success of their venture. On the other hand, the company benefited tremendously from the public capital investments done for Contorno Leste. Arguably, the municipal and state governments could have bargained for more in the way of development agreements and/or exactions to either request that the company take charge of the works or pay the costs that the developments were to impose on adjacent communities. In addition, equity considerations may 
rise from a questioning of the opportunity costs to the government of building Contorno Leste, which serves the AlphaVille developments, rather than other public works that could have more directly benefited disenfranchised citizens in the region.

\section{Glocal Architecture and Urban Design in Curitiba}

This paper has examined how recent types of housing developments in Curitiba are causing particular forms of urban alienation and anomie, while at the same time reinterpreting the meaning and form of community. The opposing concepts of community/society and alienation/progress, long considered at the heart of the conflict between tradition and modernity, seem to be heading back to reformulated instances of community and alienation as key bases of social organization. The modern, sophisticated ideals of society and progress are oftentimes contested and even combated, in favour of more primitive instances of the former socioorganizational axes-i.e. community and alienation. These states (most particularly community, with its generally positive connotations in both popular and academic cultures), are deliberate social constructs and practices established as hegemonic ways by which an elite reproduces itself and exercises political, economic and symbolic power over its society in a globalized world.

In addition to the elicitation of urban alienation and anomie — or perhaps through it—dialectic tensions and dialogical relations between local and global ways of life in Curitiba are expressed through the production of the specific types of architecture and urbanism reviewed in this paper, resulting in a hybrid modern/post-modern built environment where global design traditions are 'localized', creating new syncretistic meanings and forms. As the examples show, these conditions signal both the workings of homogenizing globalization pressures on the local design, planning and governmental elite of the city, and processes of assimilation of the higher-income tiers of society to the new spatial orders. These local elites are the main instrument by which Curitiba undergoes a top-down transformation that aims to increase its attractiveness for foreign and national capitals, while putting in place mechanisms of social, economic and spatial exclusion for the majority of its citizens.

Significantly enough, the turning back to community in many contemporary societies is often coexistent with a fast-paced development and application of technology, and hence, a process rife with social, cultural and spatial conflicts and paradoxes. The current condition of spatial (post) modernity in Curitiba also expresses processes of societal change in the city. The caveat is that while the type of society that ensues has been commonly regarded elsewhere in the First World as 'post-industrial society' (Bell, 1976), and linked to other definitions such as informational or network society (Castells, 1989, 1996), in Curitiba the advent of this type of society is more unevenly developed than in most First World cities, leading to greater inequality and polarization. Indeed, it can be seen as strongly focusing on the unbalanced exacerbation of the conditions of urban alienation and anomie, resulting in a progressive abandonment of the public realm.

The varied explanations and case studies of the gated community and edge city phenomena in the literature reflect the variety and complexity of these developments. Hence, useful analytical frameworks necessarily extend beyond the public-private realm debate and the GemeinschaftGesselschaft community sociological analyses emphasized here. Without refuting other postures, however, this analysis contributes to furthering the explanatory framework for the expanding popularity and development of gated communities and edge cities around the world in times of complex post-modern and global processes of individual and communal subjectivity 


\section{(re)constructions.}

In particular, the analytical approach emphasized here is offered to complement the one based on the post-industrial/global/informational society argument advanced by Manuel Castells (1996) and others. In the network society approach, cities are considered heterogeneous entities among and within themselves, whose fragmented parts develop differential and changing connections to the space of flows and the global economy. Accordingly, Sa o Paulo and Curitiba are not homogeneously developed information-age cities. Rather, given Brazil's strong informational sector vis-a `-vis other Latin American countries, its more developed cities-such as these twohave socio-economic and spatial sectors which are well served by digital information technology and well connected to global telecommunication networks, and hence are "places where an emerging elite of capitalist entrepreneurs and high-tech workers congregate, seeking respectively to build and consume exclusive enclaves [e.g. gated or edge cities] experienced as First-World lifestyle transplants". 9 Gated communities and edge cities as the localizing of global urban design traditions are thus "new forms of space production involving very large, often multinational private project ventures in very dynamic real estate markets”. Similarly, they represent new forms of space consumption for the aforementioned elite. It is not surprising that the first AlphaVille model was developed in Sa o Paulo and the second in Campinas—one of the leading high-tech manufacturing cities in its metropolitan region. It is also no coincidence that AlphaVille Urbanismo is aggressively tapping into the market of Curitiba, a city with a relatively larger, better-off middle class than many other cities in Brazil, and with a long-standing claim of having a high quality of life and a population with sophisticated consumption habits.

There are other local factors that also compound the Gemeinschaft-Gesselschaft argument offered here. For instance, the anomie and alienation thesis in the Latin American context in general and in Brazil in particular cannot be divorced from the consideration of both the deterioration of public order and the (sometimes overblown) perception thereof. An increased demise of public safety, which victimizes all social classes, is an unavoidable factor in explaining the growing demand to fence off communities. This may also partially explain the growing popularity of gated communities among lower-income groups too. However some studies, such as Texeira de Andrade's analysis of Belo Horizonte's gated communities, claim that a status-seeking impulse continues to be more significant than safety as motivation for middle-and lower-income groups seeking this type of development (Texeira de Andrade, 2001).

The privatization of public functions that accompanies gated communities has been also singled out in the literature as a measure that both elite and non-elite groups resort to in order to overcome the public sector service crisis in Latin America resulting from debt restructuring and inefficient or corrupt governments. In addition, due to federal retrenchment and neo-liberal policies, local governments have increasingly become dependent on public-private partnerships and schemes such as Curitiba's re-zoning of Ecoville and AlphaVilles for the promotion of highend real-estate investment; and on innovative land development exactions such as the 'created land' (solo criado) — the selling of development rights to private developers-issued to address public housing responsibilities.In any case, the new types of built environments reviewed here transform polity, as they promote changes in the character of public space and citizens' participation in public life. As the unprecedented social and spatial transformations unfold, there are no clear outcomes for the future of city polity. Is there a different political ideal (fiction)—or a lack thereof-conceptualizing urban social inequalities and differences today? If so, are the spatial patterns presented here the resulting conception of the new spatial configuration brought 
about by the new polity? Analysing the fragmentation of public space in Sa ${ }^{\sim}$ Paulo and Los Angeles, Caldeira raises the questions: "If social differences are brought to the center of the scene instead of being put aside by universalistic claims, then what kind of model for the public realm can we maintain? What kind of polity will correspond to the new fragmented public sphere?" (1999, p. 102). In turn, what kind of space would correspond to the new fragmented public sphere? Setha Low also expands this critical questioning in her work on San Jose's (Costa Rica) public spaces. She asks, for instance, "is the availability of public space a precondition for any kind of democratic politics? ... Is the threat to public space actually a threat to democracy?” (Low, 2000, p. xiv). Similarly, these questions resonate with those of Blakely \& Snyder (1997): "when the community of responsibility stops at the subdivision gates, what happens to the function and the very idea of a social and political democracy? Can [a] nation fulfill its social contract in the absence of social contact?”. One thing seems clear: the old modern fiction of the social contract and ideals of universal rights and equality seem to be increasingly losing their explanatory value, and thus the modern conception of public space increasingly becomes devalued and outdated.

This study of Curitiba's examples of gated communities and edge cities shows that despite being internationally showcased as a model of good planning and urban design, this city has not been immune to the global capital pressures and urban design tendencies occurring in many cities throughout the world. Thus, this work on Curitiba echoes the same questions about the interplays between city politics and polity and urban and architectural space that have been raised in different geographical contexts in this era of globalization-e.g. by Caldeira, Low, Blakely and Snyder, and many other scholars - signalling both the currency and trans-nationality of these issues. Aside from representing colossal challenges for practicing planners and design professionals, the undergoing changes in urban politics and the efforts needed to preserve both significant public spheres and public spaces in Curitiba—and elsewhere—pinpoint a substantial agenda for research that can no longer be postponed.

Indeed, this article presents a preliminary analysis on how design epistemologies and community formation practices-including social consequences of gated communities and political and spatial practices of urban elites - are reflected on and impacted by recent gated and edge-city communities in Curitiba. However, more research needs to be done in each of these areas. Of particular use would be the collection of further data on the people who live in these enclaves and their social relations, and on the political elites' influence on the shaping of the built environment. Additionally, greater examination of the philosophical underpinning and conflicts of the global and local urban design discourses at play in these developments remains to be done.

\section{Acknowledgements}

Thanks to JUD editor Michael Southworth and the two anonymous reviewers for their thoughtful and challenging comments. 


\section{Figures:}

Figure 1. A view of Ecoville: high-rise towers in a compartmentalized green area. The building in the foreground is Le Corbusier. Source: Courtesy of Plaenge.

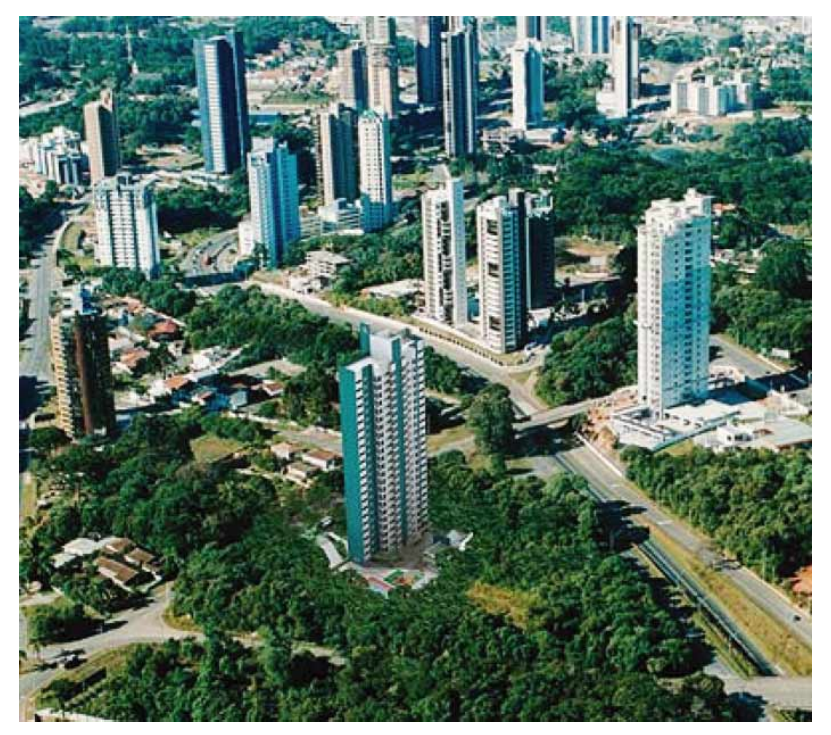


Figure 2. Controlled pedestrian and car access, and sport, social and natural amenities at the ground and lower levels of Le Corbusier: a vertical gated community. Source: Courtesy of Plaenge.

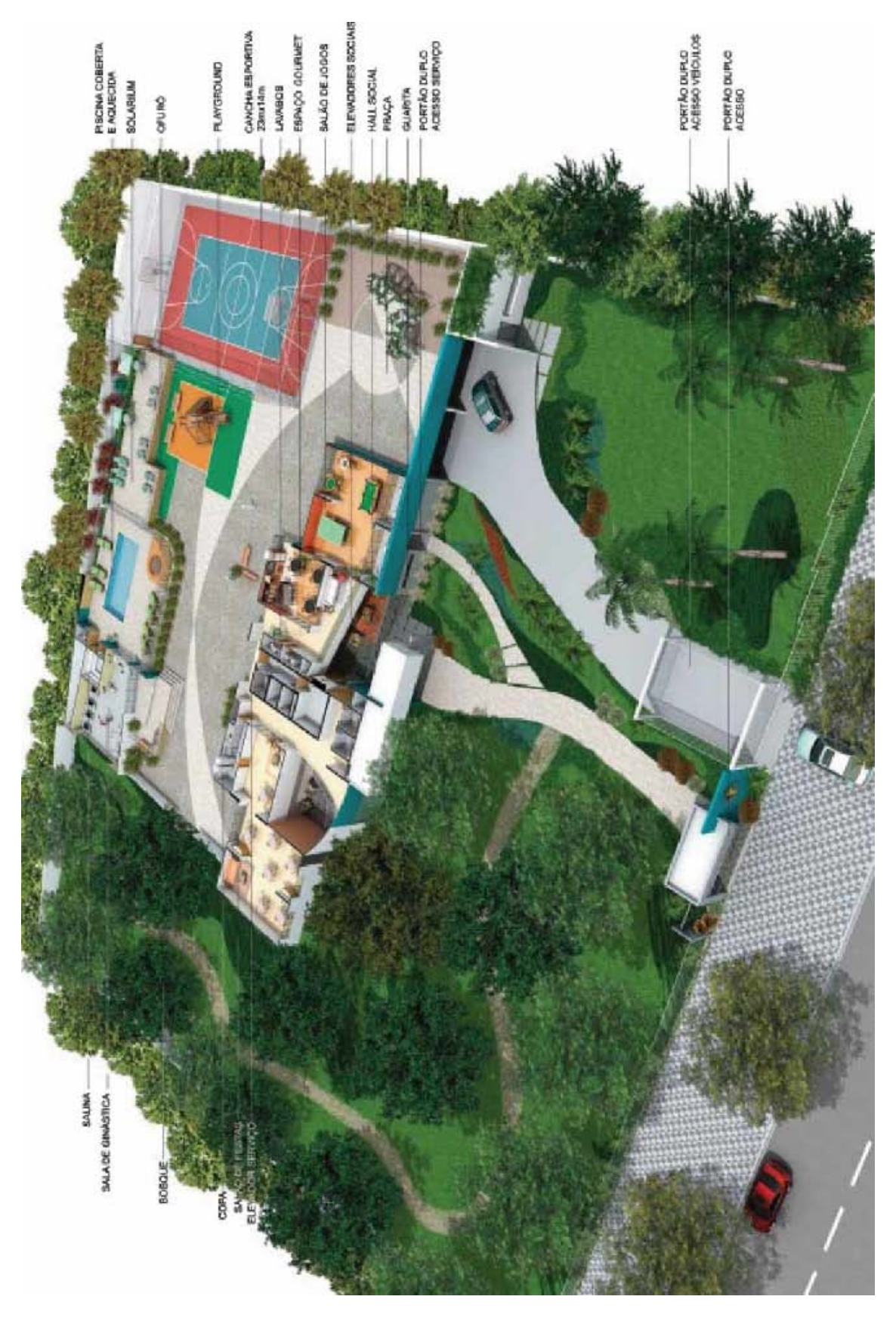


Figure3.LocationmapofSur teVollardinEcoville: the building next to Barigui Park

Figure4.RenderingofSuíteVollard: the tower on a pedestal, disengaged from the street and surrounded by a high-speed traffic corridor. Source: Courtesy of Moro.
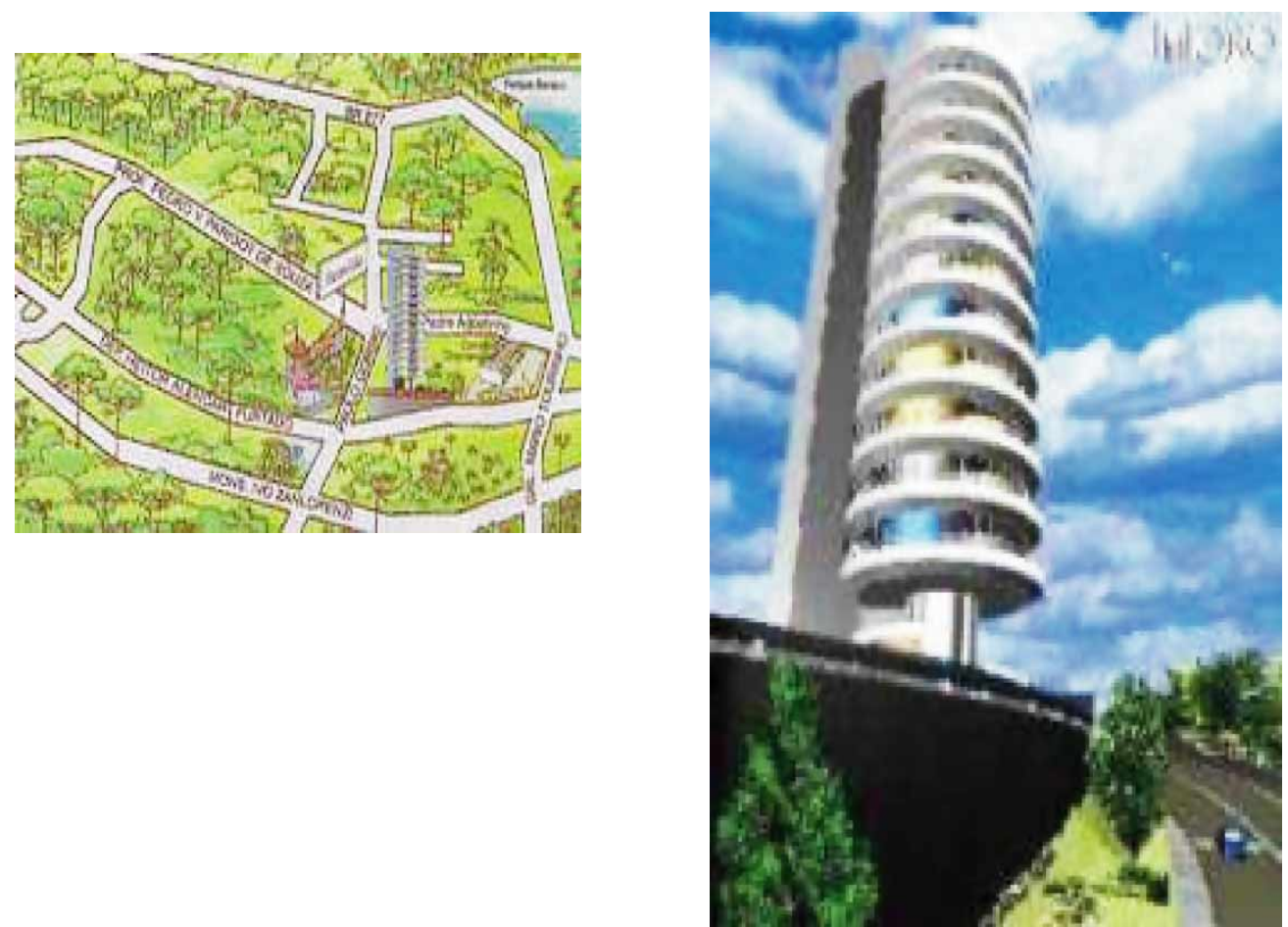

Figure 5. Apartment plan at Suíte Vollard. Each apartment rotates independently. Source: Courtesy of Moro.

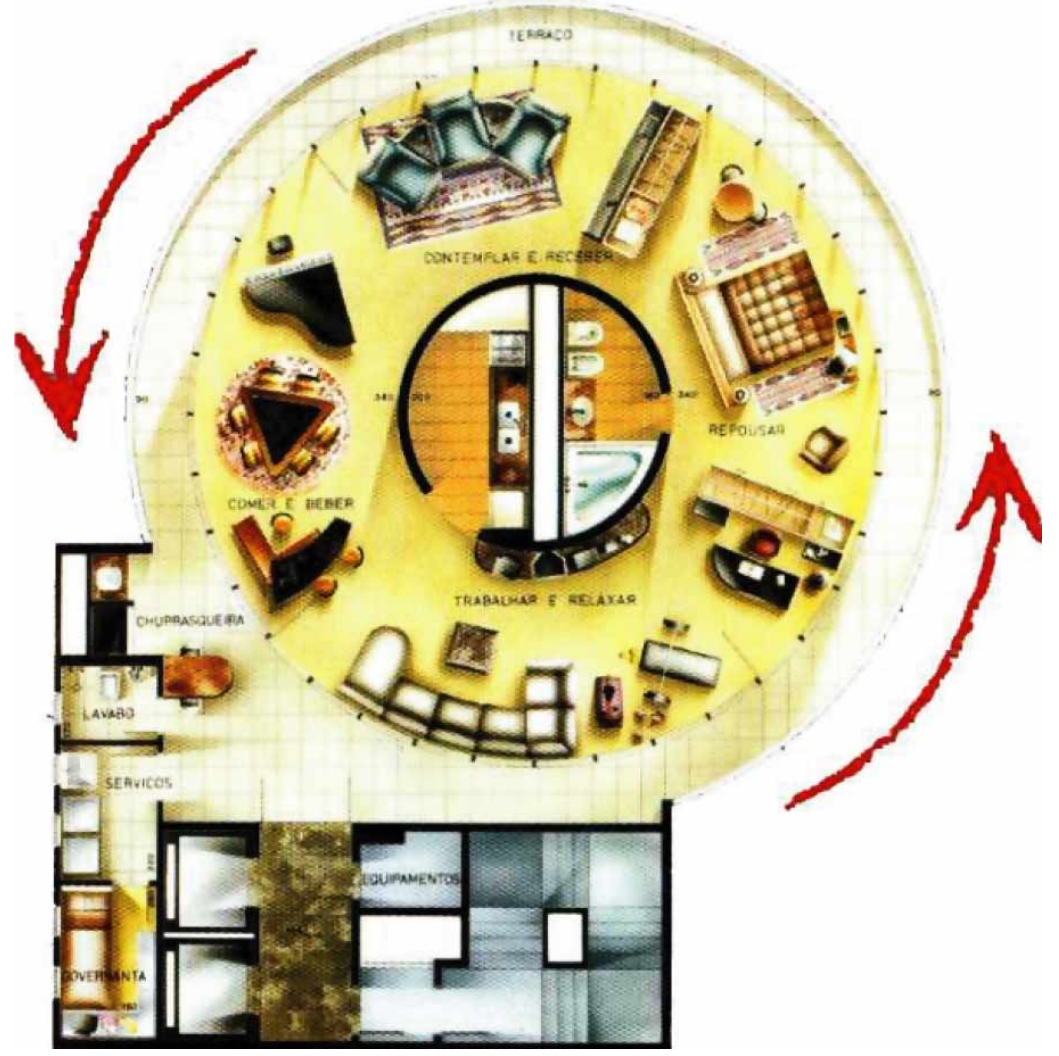


Figure 6. Private lives on display at Suı́te Vollard. Source: Courtesy of Moro.

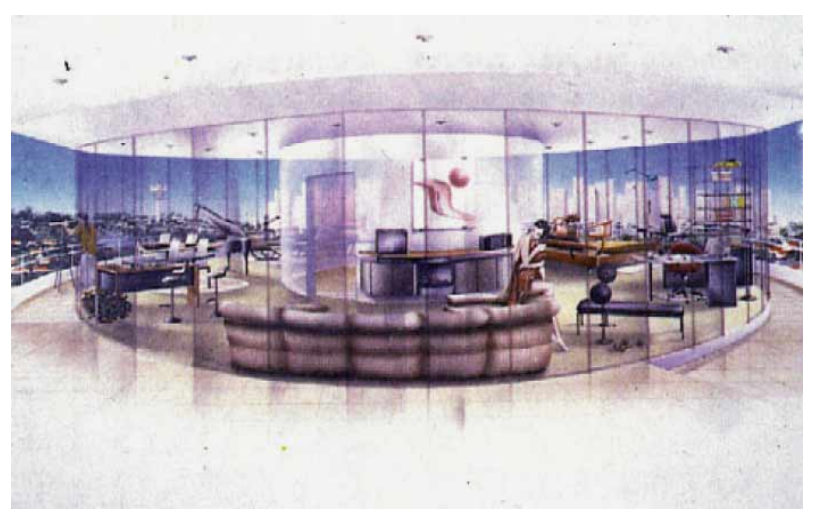

Figure 7. Master plan of Alphaville Graciosa. Source: Courtesy of Arcoweb.

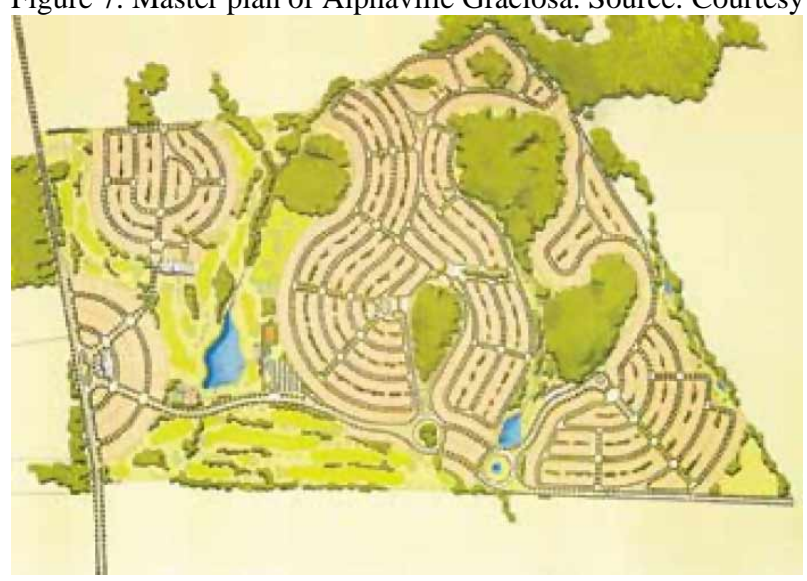

Figure 8. Club house and golf course at Alphaville Graciosa. Source: Courtesy of Arcoweb.

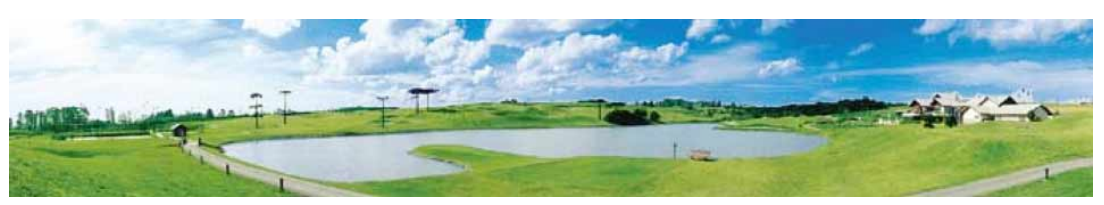

Figure 9. Alphaville Graciosa's layout. A lack of preservation of native forests is revealed, as well as a great disconnection from the traditional urban fabric and grid. Source: Courtesy of Cesbe, S.A.

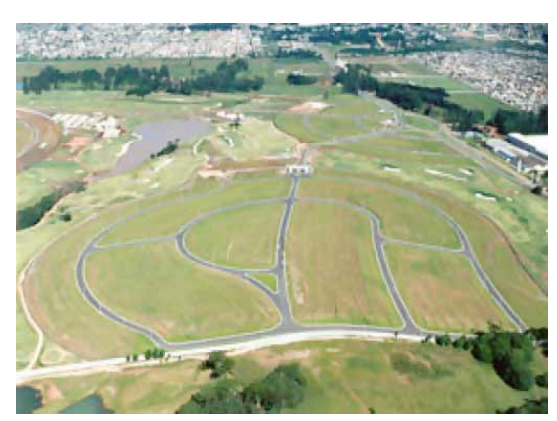


Figure10. Alpha Mallin Alphaville Graciosa.The availability of services in the subdivision makes it a hybrid gated/edge city. Source: Courtesy of Arcoweb.

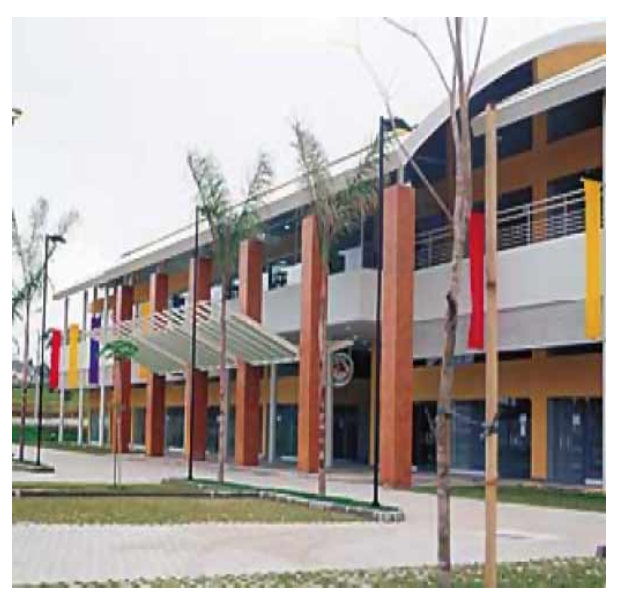


Notes

1. The German sociologist Ferdinand To"nnies introduced these terms into the social sciences in 1887, in reference to idealized types of social organization and relationships, and the transition from one to the other as an outcome of industrialization.

2. The French sociologist Emile Durkheim, in his work The Division of Social Labor (Durkheim, 1893), proposed a theory to explain the evolution from primitive to modern societies, respectively distinguished by a 'mechanical' — based on similarity between individuals_-versus an 'organic' solidarity—based on complementary differences between individuals.

3. For recent theoretical and empirical studies, refer to Housing Studies' thematic issue on gated communities, Volume 20, Number 2(March), 2005. See also Environment and Planning B: Planning and Design 2002, Volume 29 for articles with cases from the Middle East, Latin America (Argentina and Brazil), South Africa and Europe. See also Miao (2003), and Audirac (2003) for cases from Mexico and India.

4. These results are not new in the modernist tradition, however. Ecoville is just a recent example of modernist development destroying street space and producing undefined public space.

5. The municipal housing agency of Curitiba is a mixed-base company in which the municipality is the main action holder. It was created in 1965 to support housing construction for low-income groups, focusing on the population group of below three minimum salaries. This group makes up approximately $70 \%$ of the people registered on the Cohab waiting list.

6. AlphaVille Graciosa is gradually becoming inhabited. By February 2004, there were 183 residential projects approved, and more than 20 were undergoing revisions. There were 51 resident families and 93 houses being built. There was a last cluster of lots still for sale, starting from 700 square metres at R\$16 000 per square metre. Once the occupation is complete, it is expected that approximately 10000 people will be living, working and studying in the complex. In AlphaVille Pinheiros, nearly $80 \%$ of the lots had been sold by February 2004, a few months after sales began. Pinheiros is an exclusive gated residential enclave, next to the already-consolidated AlphaVille Graciosa, occupying an area of 217800 square metres, with 157 lots of an average area of 550 square metres each. The sub-division is the result of the great appreciation of land values and increased housing demand in the area since 2000, given the impact of AlphaVille Graciosa. Residents of AlphaVille Pinheiros will have privileged access to the large areas of recreation, retail, services and amenities in AlphaVille Graciosa, including the shopping mall Alpha Mall, the school Cole'gio Bom Jesus Internacional, the AlphaVille Graciosa Clube and the golf course, among other amenities (Figure 10). The price of a square metre was R\$14 500 (as of February 2004). The building of basic infrastructure was still in its initial stages.

7. CityAlpha had existed for at least four-and-a-half years (founded in November 1998), published by Parole Servic, os Editoriais Ltda., and had consolidated as a news reference in AlphaVille and the west area of greater Sa o Paulo. In February 2004, however, the site had vanished from the Internet. Representatives from AlphaVille Urbanismo told me they had never heard about CityAlpha, and the firm Parole did not respond to my inquiry about it.

8. Most recently, the term community has been significantly contested in planning literature that deals with the challenges of multi-cultural cities. For references, see Young (1990), Harvey (1997) and Day (2003), among others. 
24

9. Comments offered by anonymous reviewer.

10. Comments offered by an anonymous reviewer. 


\section{References}

Abrahamson, M. (1996) Urban Enclaves: Identity and Place in America. Series Contemporary Social Issues (New York: St. Martin's Press).

ADVB (2003) Website at: http://www.advbfbm.org.rb (accessed 21 December 2003).

AlphaVille (1999) www.alphaville.com.br (accessed 24 November).

AlphaVille (2004) www.alphaville.com.br (accessed 3 February).

Audirac, I. (2003) Information-age landscapes outside the developed world: Bangalore, India, and Guadalajara, Mexico, Journal of the American Planning Association, 69(1), pp. 16-32. Bell, D. (1976) The Coming of Post-Industrial Society: A Venture in Social Forecasting (New York: Basic Books).

Benjamin, W. (1969) transl. by H. Zahn, in: H. Arendt (Ed.) Illuminations (New York: Schocken Books).

Berger, P. L. \& Kellner, H. (1964) Marriage and the construction of reality, Diogenes 46 (Summer), pp. 1-23. (Extract in R.L. Coser (Ed.) (1974) The Family, Its Structures and Functions, pp. 157-160 (New York: St Martin's Press).

Berman, M. (1982) All that is Solid Melts into Air: The Experience of Modernity (New York: Simon \& Schuster).

Blakely, E. \& Snyder, M. G. (1997) Fortress America: Gated Communities in the United States (Washington, DC: Brooking Institution Press and Land Institute of Land Policy), available at: http://cproundtable.org/cprwww/docs/equity/05 fort.htm (accessed 5 November 2004).

Blandy, S. \& Lister, D. (2005) Gated communities: (ne)gating community development?, Housing Studies, 20(2), pp. 287-301.

Byrum, O. (1992) Edge cities: a pragmatic perspective, Journal of the American Planning Association, Summer, pp. 395-396.

Caldeira, T. (1999) Fortified enclaves: the new urban segregation, in: Low, S. (Ed.) Theorizing the City: The New Urban Anthropology, pp. 83-107 (Reader, NJ: Rutgers University Press).

Calvino, I. (1974 (orig. 1972)) Invisible Cities (San Diego, CA: Harvest).

Castells, M. (1989) The Informational City: Information Technology, Economic Restructuring, and the Urban- Regional Process (Cambridge, MA: Blackwell Publishers) .

Castells, M. (1996) The rise of the network society, in The Information Age: Economy, Society and Culture, Vol. 1 (Cambridge, MA: Blackwell Publishers).

CitiAlpha (1999a) Correio do Alvaro Garcia, Available at http://www.cityalpha.com.br/ (accessed 27 December).

CityAlpha (1999b) www.cityalpha.com.br/ (accessed 24 November).

CityAlpha (2000) Seguranc, a e’ a maior preocupac,ão da populac, ,ão, Available at http://www.cityalpha.com.br/ (accessed 27 March).

Davis, M. (1990) City of Quartz: Excavating the Future in Los Angeles (London: Verso).

Day, K. (2003) New urbanism and the challenges of designing for diversity, Journal of Planning Education and Research, 23, pp. 83-95.

Durkheim, E. (1893) The Division of Labor in Society, trans. by D.W. Halls (1984) (New York, NY: Free Press).

Ellin, N. (1996) Postmodern Urbanism (Cambridge: Blackwell Publishers).

Epoca (1998) Arquitetura: O Pião da Casa Pró pia, Curitiba, 17 August, available at http://revistaepoca. globo.com (accessed 17 August).

Folha de São Paulo (1999) Procura por Casas em Condomı́nios Fechados, São Paulo, 3 October.

Garreau, J. (1991) Edge City: Life on the New Frontier (New York: Anchor Books/Doubleday). 
Harvey, D. (1985) Consciousness and the Urban Experience: Studies in History and Theory of Capitalist Urbanization (Baltimore, MD: The Johns Hopkins University Press).

Harvey, D. (1997) The New Urbanism and the communitarian trap, Harvard Design Magazine, Winter/Spring, pp. 1-3.

Holston, J. (1989) The Modernist City: An Anthropological Critique of Brasilia (Chicago, IL: University of Chicago Press).

Kostof, S. (1991) The City Shaped: Urban Patterns and Meanings Through History (Hong Kong: Bulfinch Press).

Le Corbusier (1973) The Athens Charter, trans. by A. Eardley (New York, NY: Grossman Publishers).

Low, S. (2000) On the Plaza: The Politics of Public Space and Culture (Austin, TX: University of Texas Press).

Low, S. (2003) Behind the Gates: Life, Security and the Pursuit of Happiness in Fortress America (New York: Routledge).

Marshall, G. (1994) The Concise Oxford Dictionary of Sociology (Oxford: Oxford University Press).

Miao, P. (2003) Deserted streets in a jammed town: the gated community in Chinese cities and its solution, Journal of Urban Design, 8(1), pp. 45-66.

Moro S/A Construc, o es Civis (1994) Vollard: Um Giro Panora^mico de 360 Graus, Informativo Moro, I(3) (brochure).

Moro S/A Construc, ões Civis (2000a) Estac,ão Plaza Show, Available at http://www.moro.com.br/news_estacao.htm (accessed 20 March).

Moro S/A Construc, oes Civis (2000b) Moro’s web wage, Available at http://www.moro.com.br (accessed 23 March).

Moro S/A Construc, ões Civis (2003) Website at: http://www.moro.com.br (accessed 21 June 2003).

Newman, O. (1972) Defensible Space: Crime Prevention through Urban Design (New York: Macmillan).

Nisbet, R. A. (1966) The Sociological Tradition (New York: Basic Books).

Orfield, M. (1998) Portland Metropolitics: A Regional Agenda for Community and Stability, A Report to the Coalition for a Livable Future, Portland (Portland, OR: Coalition for a Livable Future), available at: http://www.clfuture.org/publications/Orfield/index-html.

Rapaport, R. (1998) Kaplan, McLaughlin, Diaz: Placemaking: Innovation and Individuality (Gloucester, MA: Rockport).

Recicla'veis (2004) Website at: http://reciclaveis.com.br.

Sanchez, F. (2003) A Reinvenc, a o das Cidades para um Mercado Mundial (Chapecó, SC, Brasil: Argos).

Seeman, M. (1959) On the meaning of alienation, American Sociological Review, 24(6), pp. 783-791.

Texeira de Andrade, L. (2001) Condominios Fechados da Regia o Metropolitana de Belo Horizonte: Novas y Velas Experiencias, in: Etica, Planejamento e Construc,ão Democrática do Estado (Rio de Janeiro: Associac,ão Nacional de Pos-Graduac,ão e Pesquisa em Planejamento Urbano e Regional ANPUR).

Urban, T. (1998) Interviewed by R. Moura \& M. de Lourdes Kleinke, Avaliac, ão de experie^ncias em planejamento de Cidades. Entrevistas Curitiba, Instituto Polis, Curitiba, 8 April.

Veja (1999) Maurı́cio Mattar Critica Alphaville, Veja São Paulo, 7 November, available at: http://vejaonline.abril.com.br (accessed 24 November 1999). 
Young, I. M. (1990) Justice and the Politics of Difference (Princeton, NJ: Princeton University Press). 